\title{
GENRE TABAQAT
}

\author{
Syukri \\ Universitas Islam Negeri Sumatera Utara (UINSU) Medan \\ ssyukri85@yahoo.com
}

\begin{abstract}
Abstrak
Genre Tabaqat adalah jenis-jenis kitab yang merupakan kumpulan-kumpulan biografi tokoh berdasarkan tingkatan generasi. Isi dari Tabaqat bisa berupa pengklasifikasian tokoh-tokoh tertentu yang memiliki satu atau lebih kesamaan. Suatu karya dapat saja memilih kelompok tertentu seperti para fuqaha, para mufassir, para sasterwan, para sufi, para filosof, para ahli tata bahasa, para hakim, para rektor di satu perguruan tinggi tertentu dan seterusnya sebagai tema. Pendekatan biografis membuat karya jenis ini sangat kaya dan dapat berisi apa saja. Biografi membawa satu kekuatan tersendiri karena dia merujuk langsung pada realitas kehidupan, prilaku seseorang, praktik kerjanya, metodologi yang dianutnya, dan teknik-teknik yang diterapkannya.
\end{abstract}

Kata Kunci : Genre dan Tabaqat

\begin{abstract}
Tabaqat genres are types of books which are biographical collections of figures based on generations. The contents of Tabaqat can be in the form of classifications of certain figures who have one or more things in common. A work can choose certain groups such as the jurists, mufassir, sasterwan, Sufi, philosophers, grammarians, judges, chancellors in one particular university and so on as themes. The biographical approach makes this type of work very rich and can contain anything. Biography carries a power of its own because it refers directly to the reality of life, one's behavior, work practices, the methodology adopted, and the techniques that it applies.
\end{abstract}

Keywords: Genre and Tabaqat

\section{Pendahuluan}

Salah satu kelebihan yang dimiliki dunia intelektual Islam adalah adanya jenis (genre) kitab yang disebut tabaqat (tabaqat). Secara harfiah dapat dimaknai sebagai genus, kelas, kategori, atau mungkin yang lebih tepat : klasifikasi. Isinya adalah pengklasifikasian tokoh-tokoh tertentu yang memiliki satu atau lebih kesamaan.

Kesamaan tersebut dapat dalam bentuk periode kehidupan tertentu yang sama, lokasi geografis yang sama, spesialisasi keilmuan yang sama, jabatan tertentu yang sama, atau penggabungan faktor-faktor yang memiliki kesamaan yang disebutkan di atas. Sehingga tabaqat kurang lebih seperti kamus biografi.

Meski demikian, ada juga tabaqat yang berisi hanya tentang satu tokoh sehingga sama dengan bentuk biografi yang lazim kita kenal. Contohnya adalah Kitab al-Tabaqat al-Imam alMubaddisy Abi 'Amru Khalifatu-bnu Khayyat Syabab al-'Ashfury, (wafat $240 \mathrm{H}$ ), yang merupakan tesis 
Ikram Dliya' al-'Amri dalam bidang Sejarah Islam di Universitas Baghdad tahun 1966 dan diterbitkan setahun kemudian oleh universitas tersebut.

Sebagian besar isi tabaqat dapat langsung dikenali dari judulnya, semisal karya Ibn alFaradi, Kitab al-Mawsul fi Tarikh 'Ulama' al-Andalus, yang sudah pasti berisi sejarah tentang ulamaulama di atau dari Andalus. Atau kitab tabaqat berikut yang akan dibahas lebih detil, Al-Nur alAbhar: Fi Tabaqati Syuyukh al-Jami' al-Az̧har karya Muhyi al-Din al-Tu'mi, yang sudah pasti berisi para syekh yang pernah memimpin (menjadi rektor) Universitas al-Azhar. Satu kitab tabaqat lainnya yang juga dikemukakan berikut adalah Tabaqat asy-Syafi iyah karya Ibn Qadhiy Syuhbah. Tabaqat pertama disusun berdasar abjad dari alif sampai ya, dan tabaqat kedua secara kronologis.

\section{Al-Nur al-Abhar : Fi Tabaqati Syuyukh al-Jami' al-Azhar}

Kitab tabaqat ini terbitan Jami’ al-Huquqi Mahfuzati li Dar al-Jil, Beirut, tahun 1412/ 1992. Pengarangnya Muhyi al-Din al-Tu'mi juga adalah pengarang sejumlah 20 kitab tabaqat lainnya, antara lain al-Tabaqat al-Kubra fi Tarajim Auliya'a al-Ummati al-Mubammadiyati sebanyak 20 juz, Tabaqat al-Nisaa' al-Mutashawwafat, Mu'jam Karamati al-Shahabati, dan Tabaqat Abl al-Bait.

Terdapat biografi ringkas dari 87 syuyukh al-Azhar pada kitab tabaqat ini yang keseluruhannya terangkum dalam 138 halaman. Ke-87 nama tersebut dikemukakan di bawah ini, meski karena sejumlah keterbatasan, sebagian besar nama tidak dipaparkan dengan penjelasan sebagaimana dimuat dalam kitab tabaqatnya ; hanya sebatas menyebut periode kepemimpinannya.

1. Ibrahim al-Barmawi : Syekh al-Azhar kedua yang menggantikan Syekh Muhammad alHarsyi tahun $1101 \mathrm{H}$ dan memimpin sampai 1105. Nama lengkapnya Ibrahim bin Muhammad bin Syihab al-Din bin Khalid al-Barmawi, dan dikenal sebagai bujjah dalam Fiqh Syafii.

2. Ibrahim al-Baijuri : Ibrahim bin Muhammad al-Baijuri al-Syafi'i merupakan Syekh alAzhar yang ke-19 sejak tahun 1263 (1847 sampai 1860) setelah wafatnya Syekh al-Azhar ke-18 ; Syekh Ahmad 'Abd al-Jawwad. Sepanjang karirnya, Ibrahim al-Baijuri mengajarkan Ilmu Tauhid mulai dari selesai shalat Zuhur hingga menjelang shalat Ashar, dan termasuk di antara muridnya ialah Raja Mesir Abbas I.

3. Ibrahim Hamrusyi : Syekh al-Azhar ke-34 adalah Ibrahim Hamrusyi yang merupakan murid langsung dari Muhammad 'Abduh, dan sebelum menjadi Syekh al-Azhar pada tahun 1951 dikenal sebagai guru Bahasa Arab dan memimpin sejumlah madrasah tingkat dasar dan menengah. 
4. Ibrahim al-Fayumi : Ibrahim bin Musa al-Fayumi merupakan Syekh al-Azhar yang ke-6 sejak tahun 1133 hingga wafat $1137 \mathrm{H}$.

5. Ahmad bin Abd al-Jawwad : Syekh al-Azhar ke-18 yang juga bermazhab Syafii. Wafat $1263 \mathrm{H}$, sedang tahun lahirnya tidak ada tercantum. Murid dari Syekh Muhammad Syanwani (syekh al-Azhar ke- 13) dan Syekh 'Ahmad Damhuji (syekh al-Azhar ke-15).

6. Ahmad bin 'Abd al-Haq Syihab al-Din al-Sanbati : Ulama mujtahid bermazhab Syafii, wafat di Makkah tahun $950 \mathrm{H}$. Tidak diungkapkan sebagai syekh al-Azhar yang keberapa.

7. Ahmad bin Muhammad Syams al-Din 'Abu al-Abbas ibn Khalqan : Pengarang kitab Wafiyat al-A'yan yang terdiri dari dua jilid dengan jumlah halaman sebanyak 557. Lahir 607 dan wafat $681 \mathrm{H}$. Tidak disebutkan pula sebagai Syekh al-Azhar yang keberapa, hanya disebut kalau ia telah mengajar di al-Azhar tahun 637.

8. Ahmad bin Muhammad bin Atho' Allah al-Iskandariy : Pengarang sejumlah kitab, yaitu al-Hukm, Taj al-'Urus, Latha'if al-Mannan. Ia merupakan murid dari Ibn Taimiyah.

9. Ahmad al-Dardir : Wafat 1209 H. Salah satu karyanya adalah al-Manæhumah fi al-Tashauf.

10. Ahmad al-Dahmuji : Nama lengkapnya Ahmad bin Ali bin Ahmad al-Dahmuji al-Syafi'i, kelahiran Kairo tahun 1170 dan merupakan Syekh al-Azhar yang ke-15 dari tahun 1245 sampai 1246; tahun wafatnya.

11. Ahmad al-Damanhuri : Nama lengkapnya Ahmad bin Abd al-Mun'im bin Yusuf alDamanhuri al-Syafi'i, kelahiran Al-Damanhuri tahun 1101, dan menjadi Syekh al-Azhar yang ke-10 mulai tahun 1171. Menulis sejumlah kitab "ensiklopedis" seperti Minhaj alSuluk fi Nashihat al-Muluk (Tasawuf), Risalah 'Ain al-Hayati fi Istinbathi al-Miyah (Geologi), Fath al-Rabbani fi Mufradat Ibn al-Syaibani (Fiqh), dan dalam bidang Hadis serta Balaghah.

12 Ahmad al-Thahthawi : Ahmad bin Muhammad al-Thahthawi adalah syekh yang dikenal hanif pada masanya, menjadi syekh al-Azhar hanya dari tahun 1230 sampai $1231 \mathrm{H}$.

13. Ahmad al-'Aroushi : Ulama kelahiran $1133 \mathrm{H}$ ini dikenal sebagai ahli tasawuf dan balaghah, dan merupakan syekh al-Azhar yang ke-11 dari tahun 1778 sampai 1793 M. Wafat tahun $1208 \mathrm{H}$.

14. Ahmad Syakr : Ahmad Syakr adalah ulama hadis terkemuka Mesir dan pernah menjadi qadli di Sudan dan Mesir. Data lahirnya agak lengkap : Jum’at 29 Jumadil Akhir 1309.

15. Ahmad al-Showi ; wafat 1241.

16. Ahmad 'Abd al-Rahman al-Banna al-Sa'ati, ayah dari Hasan al-Banna, pengarang kitab Fath al-Rabbani fi Tartib Musnad al-Imam Ahmad ibn Hanbal al-Syaibani.

17. Al-Hasan bin Ibrahim bin Naulaq al-Mashri, salah satu ulama terkemuka Mesir pada era Fathimiyah, wafat $387 \mathrm{H}$. 
18. Hasan al-'Athar, syekh al-Azhar ke-16 antara 1830-1834, saat Mesir berada di bawah pendudukan Perancis. Wafat $1250 \mathrm{H}$, pengarang Risalah fi Kaifiyat al-'Amal bi al-Astrolab dan Kitab fi al-Insya' wa al-Murasilat.

19. Hasan al-Quwaisni : Syekh al-Azhar ke-17 dari 1250 sampai $1254 \mathrm{H}$, pengarang kitab Syarah 'ala Matan Sullam dan Risalah fi al-Mawarisy.

20. Husnain Muhammad Makhluf : Antara lain mengarang Risalah fi al-Qur'an al-Karim wa Fadbilah al-Azhim wa Adab Tilawatih wa Sama'ah.

21. Hasunat al-Nawawi, menjadi syekh al-Azhar pada 1896 sampai $1900 \mathrm{M}$ dan setelah disela oleh tiga syekh lainnya, kembali diangkat menjadi syekh al-Azhar pada 1909 M.

22. Hamzah Fath al-Lah : Lahir di Iskandariah 1266 H/1849 M, pakar bahasa Arab dan Hif 2 h al-Qur'an, mengarang sejumlah buku dalam dua bidang tersebut.

23. Rifa'at Rafi' al-Thahthawi.; menguasai disiplin ilmu nahwu dan geografi, wafat $1290 \mathrm{H}$.

24. Salamat al-'Azami : ulama pengembang Tarikat Naqsyabandi di Mesir.

25. Salim al-Bisyri, kelahiran $1247 \mathrm{H}$, menjadi syekh al-Azhar dalam dua periode terpisah ; 1317 sampai 1320 dan dari 1327 sampai $1335 \mathrm{H}$.

26. Sulaiman al-Halabi. 27. Said bin 'Ali al-Murthifi.

28. Syams al-Din al-Anbabi. 29. Solah al-Ja'fari.

30. Thahir bin Ahmad Abu al-Hasan Ibn Babsyad.

31. Thantawi Jauhari, antara lain mengarang Kitab al-Jawabir fi Tafsir al-Qur'an setebal 27 juz.

32. Thaha Hussain, ulama buta, kelahiran 1889, pernah menjadi menteri pendidikan Mesir tahun 1950, meraih doktor tahun 1917 di Universitas Mesir (al-Jami'ah al-Mashriah), dan setahun kemudian (1918) dari Universitas Sorbonne, Perancis. Menulis sejumlah buku tentang sejarah dan filsafat.

33. 'Abd al-Baqi al-Qaliani, syekh al-Azhar ke-4 dari tahun 1708 sampai $1711 \mathrm{M}$.

34. 'Abd al-Rahman Taj, syekh al-Azhar ke-36, antara lain menulis Kitab al-Islam wa Ushul alHikam.

35. 'Abd al-Rahman al-Jabaruti.

36. 'Abd al-Rahman Jalal al-Din al-Suyuthi memiliki nama lengkap 'Abd al-Rahman ibn Abi Bakr ibn Muhammad ibn Sabiq al-Din ibn al-Fahr 'Usman al-Khudoiri al-Suyuthi, dan lebih dikenal sebagai Jalal al-Din al-Suyuthi. Menguasai banyak disiplin ilmu, dan terutama tasawuf. Tetapi lebih terkenal sebagai salah satu dari pengarang Tafsir Jalalain.

37. 'Abd al-Rahman al-Syarbaini. 38. 'Abd al-Rahman al-Munawi.

39. 'Abd al-Rahman al-Nawawi. 40. 'Abd al-Rauf al-Suhyuni.

41. 'Abd al-Rauf al-Munawi. 
42. 'Abd al-Halim Mahmud, syekh al-Azhar ke-46 tahun 1973 sampai 1978 M.

43. 'Abd al-'Aziz al-Jawisyi.

44. 'Abd al-Qadir al-Rafi'i.

45. 'Abd al-Lah al-Syabrawi.

46. 'Abd al-Lah al-Syarqawi.

47. 'Abd al-Muhid Salim.

48. 'Abd al-Wahab al-Sya'rani.

49. 'Abd al-Wahab al-Najjar.

50. 'Ali ibn Ibrahim al-Khoufi.

51. 'Ali ibn 'Abd al-Rahman Abu al-Hasan ibn Yunus.

52. 'Ali ibn 'Ali Nur al-Din al-Syibramalisi.

53. 'Ali ibn Yahya Nur al-Din al-Zabadi.

54. 'Ali al-Bablawi.

55. 'Ilyasy al-Malaki.

56. 'Umar ibn al-Fard.

57. Muhammad ibn Ahmad al-'Arousi.

58. Muhammad ibn Barkat.

59. Muhammad ibn Salamat al-Qadla'i.

60. Muhammad ibn Sa’id Dalal al-'Aqali.

61. Muhammad ibn 'Abd al-Baqi al-Zarqani.

62. Muhammad ibn Mushtafa al-Maraghi.

63. Muhammad Abu al-'Uyun.

64. Muhammad Abu al-Fadl al-Jizawi.

65. Muhammad Amin al-Kurdi.

66. Muhammad al-Ahmadi al-Zhawahri.

67. Muhammad al-Amir al-Malaki.

68. Muhammad al-Kharasyi : Universitas al-Azhar didirikan oleh Daulat Fathimiyah pada tahun $975 \mathrm{M}$, dan secara resmi Muhammad al-Kharasyi menjadi syekh al-Azhar pertama. Sebelumnya, selama hampir tujuh abad, al-Azhar dipimpin langsung oleh raja. Nama lengkapnya Muhammad ibn Jamal al-Din 'Abd Allah ibn 'Ali al-Kharasyi. Lahir tahun 1601/1010 di Abu Khirasy, Propinsi Bukhaira, Mesir, dan wafat 1690/1101. Tahun wafatnya adalah tahun berakhirnya masa kepemimpinannya sebagai syekh al-Azhar, sedang tahun pengangkatannya tidak tercantum dalam tabaqat ini. Dikenal sebagai pakar fiqh Maliki, al-Kharasyi mengarang sejumlah kitab, antara lain al-Sharh al-Kabir liMukbtasar Khalil, al-Fara id al-Saniya fi Hall Alfazh al-Sunusiya, serta Muntaba al-Raghba fi Sharh al-Nukbba.

69. Muhammad al-Khidr al-Husain.

70. Muhammad al-Khudri. 
71. Muhammad Rasyid Ridla.

72. Muhammad Syams al-Din al-Hafni.

73. Muhammad al-Syanwani.

74. Muhammad al-'Abbasi.

75. Muhammad 'Abduh.

76. Muhammad 'Ali al-Tha'ami.

77. Muhammad Fu'ad 'Abd al-Baqi.

78. Muhammad al-Qailani al-Azhari.

79. Muhammad Ma'mun al-Syanawi.

80. Muhammad Mutawali al-Sya'rawi.

81. Muhammad Murtadla al-Zabidi : Dikenal sebagai ahli hadis dan bahasa Arab.

82. Muhammad al-Nasyruti : Syekh al-Azhar ke-3 dari tahun 1106 dan wafat $1120 \mathrm{H}$, penganut mazhab Maliki.

83. Mahmud Syaltut : Ulama fiqh yang hafal al-Quran ini menjadi Syekh al-Azhar yang ke-37 setelah sebelumnya lama bekerja sebagai guru di Ma’had Iskandariah. Dikenal sebagai penulis produktif dengan sejumlah karyanya antara lain, Figh al-Qur'an wa al-Sunnah, Maqarinat al-Mad₹hahib, Al-Qur'an wa al-Qital, Al-Qur'an wa al-Mara'ah, Al-Fatawa.

84. Al-Masbuhi : Nama lengkapnya Al-Masbuhi al-'Amir al-Mukhtar 'Abd al-Malik ibn Muhammad ibn 'Abd al-Lah ibn Ahmad al-Harani. Tidak dicantumkan tahun lahirnya, hanya disebut ia wafat dalam usia sekitar 54 tahun pada tahun 420. Dikenal sebagai penulis yang sangat produktif.

85. Mushtafa ibn Muhammad al-'Arousi: Syekh al-Azhar ke-10 dari tahun 1281 sampai 1287, menggantikan Syekh Ibrahim al-Baijuri. Salah satu karya al-'Arousi yang dicantumkan adalah kitab tasawuf Syarah 'ala al-Risalah al-Qasiriah. Yang menarik, ayah dan kakeknya pun sebelumnya adalah syekh al-Azhar juga, yaitu Muhammad al-'Arousi dan Ahmad al-'Arousi.

86. Mushtafa 'Abd al-Razaq : Adalah murid Muhammad 'Abduh ketika masih kuliah di alAzhar. Pernah menjadi dosen tamu di Universitas Sorbonne, Perancis, mengajar bahasa Arab dan Hukum Islam, sekaligus merangkap sebagai mahasiswa. Hasilnya ia pun memperoleh ijazah dari Sorbonne dalam ilmu filsafat dan sastra Perancis. Menjadi menteri wakaf Mesir sebelum akhirnya dipilih sebagai syekh al-Azhar pada tahun 1945 sampai 1947. Dia menerjemahkan buku Risalah Taubid Imam Mubammad Abduh ke bahasa Perancis, disamping mengarang sejumlah kitab filsafat, antara lain Al-Tahmid li-Tarikh alFalasifah dan Failasuf al-'Arabi wa al-Mu'allim al-Tsani, serta menulis biografi Imam Syafi'i 
dan Muhammad Abduh. Pandangannya yang mendukung sekularisme menyebabkan ia harus melepaskan kedudukannya sebagai Syekh al-Azhar. Di Indonesia, pemikirannya itu dijadikan sebagai hujjah oleh Soekarno dalam polemiknya tentang sekularisme dengan Muhammad Natsir.

87. Yusuf al-Dujawi : Dikenal sebagai mufassir dan mubaddisy disamping sebagai pakar fiqh mazhab Maliki. Kumpulan tulisannya pada Majalah Al-Islam dibukukan dengan judul Maqalat wa Fatawa Syekh Yusuf al-Dujawi. Syekh 'Abd al-Jalil Qasim dalam kitabnya, AlManar al-Hadi fi Manaqib Syaikhnna al-Qadli menyebut Yusuf al-Dujawi berada pada silsilah ke-75 dari garis keturunan Khalifah Abu Bakar Siddiq. Di samping itu merupakan murid dari Syekh Muhammad al-Hafiz al-Tijani.

\section{Struktur Umum Al-Nur al-Abhar : Fi Tabaqati Syuyukh al-Jami' al-Azhar}

Umumnya kitab-kitab tabaqat, sebagaimana Al-Nur al-Abhar : Fi Tabaqati Syuynkh al-Jami' al-Az̧har disusun dengan model alfabetis yang dimulai dari alif dan berakhir dengan ya. Model seperti ini memudahkan bagi pembaca yang telah mengetahui satu dua tokoh yang pernah memimpin Al-Azhar dan ingin mencari keterangan tentang tokoh yang diperlukannya, tetapi menyulitkan bagi pembaca yang berangkat dari ketidaktahuan tentang Al-Azhar. Bagi kelompok pembaca jenis terakhir akan lebih bermanfaat seandainya tokoh-tokoh disusun berdasar kronologi, karena dengan demikian memudahkan dalam memahami sejarah perkembangan kepemimpinan di Al-Azhar dari awal.

Tetapi bagaimanapun harus disadari, pengarangnya memang nampaknya tidak bermaksud menulis tentang sejarah kepemimpinan Al-Azhar; apalagi menganalisis dan mendeskripsikannya. Yang dia lakukan hanyalah sebatas mengumpulkan data yang bisa dikumpul saja. Artinya terkesan tidak ada usaha melengkapi data setiap tokoh secara seragam, sehingga kita bisa melihat bagaimana tokoh yang satu ditulis dengan cukup lengkap tapi tokoh lainnya hanya dipaparkan sebagai syekh al-Azhar yang ke-sekian saja, bahkan terkadang tidak ada. Jika sumbernya dari dokumentasi Al-Azhar, ini agak mengherankan bagaimana perguruan tinggi sekaliber Al-Azhar tidak punya dokumentasi yang komprehensif tentang rektor-rektornya. Tetapi jika kondisi ini datang dari pengarang, yang mengherankan adalah apakah yang bersangkutan tidak pernah menelusurinya ke sumber primernya di Perpustakaan Al-Azhar dan semata hanya mengandalkan kitab Mawsu'ah al-Azhar.

Hasilnya adalah kita tidak memperoleh kitab yang menarik, dan hanya sebatas menemukan sekumpulan data yang, meskipun berharga, tetapi tersaji secara "kering" dalam sebuah kitab. Dengan demikian, kitab tabaqat agaknya hanya bermanfaat bagi pembaca yang 
bermaksud melengkapi data-data dasar tentang seorang atau beberapa tokoh pada saat hendak menulis karya lain yang berkaitan dengan tokoh tersebut.

\section{Tabaqat al-Kabir}

Tabaqat lain yang tergolong sangat berharga sebagai referensi sejarah Islam adalah Tabaqat al-Kabir karya Muhammad Ibn Sa'ad ibn Mani al-Zuhri (148-230 H). Ibn Sa'ad, yang sebelumnya adalah budak (mawla) Bani Hashim yang kemudian dimerdekakan, dikenal sampai saat ini sebagai salah satu sejarawan Islam yang paling otoritatif. Gurunya yang terkemuka sewaktu di Baghdad adalah Muhammad ibn 'Umar Al Waqidi (w. 211 H). Tokoh kelahiran Basrah ini sepanjang hidupnya juga melakukan rihlah ilmiah ke Kufah dan Madinah, meski bagian terbesar dari kehidupannya dilewatkan di Baghdad dimana ia menjadi sekretaris gurunya, al-Waqidi.

Tabaqat al-Kabir berisi kisah dan biografi lebih dari empat ribu tokoh terkemuka dalam Islam, dimana 600 di antaranya adalah tokoh wanita yang ia rangkum seluruhnya dalam jilid kedelapan dari sembilan jilid buku tersebut (Beirut, 1968). Dua jilid yang pertama, mutlak ia dedikasikan isinya sebagai sirah Rasulullah saw, yang dipandang sebagai satu dari tiga sirah yang paling otoritatif tentang Rasulullah di samping Sirat al- Nabawi dari Ibn Hisham dan Maghaazi Rasulullab karya gurunya, al-Waqidi. Kemudian jilid 3 dan 4 berisi para sahabat, kebanyakan yang menyertai Rasulullah saw hijrah dan yang ikut dalam perang Badr. Bagian ini kemudian diterjemahkan terpisah ke bahasa Inggris oleh Aisha Bewley dengan judul Men of Madina, dan jilid 8 menjadi Women of Madina.

Bagian yang terangkum dalam jilid 5 sampai 7 juga berisi biografi para sahabat dan tabiin yang tidak termasuk dalam kategori Men of Madina.

Tabaqat al-Kabir ini kemudian diterbitkan ulang dalam 15 jilid oleh orientalis Jerman, Eduard Sachau, dan judulnya pun berubah menjadi Tabaqat al-Kubra (Das Classenbuch des Ibn Sad) (Leiden, 1904)

Beda dengan Al-Nur al-Abhar, karya Ibn Sa'ad ini tergolong sangat kaya dalam data dan mengungkap banyak fakta mengenai dimensi sosial tokoh-tokoh yang dia tulis. Meskipun mengandung sejumlah kontroversi tentang kesahihan kisahnya, tabaqat ini tergolong enak dibaca. Berikut sebagian kutipan :

\section{Abu Lu'lu'ah dan Umar ibn Khattab}

“Abu Lu'lu'ah adalah budak Mughira ibn Shu'ba, gubernur Basra yang juga salah satu sahabat Rasulullah saw. Abu Lu'lu'ah memperoleh izin Mughira dan juga Khalifah Umar ibn Khattab untuk menetap di Madina dan bekerja sesuai keahliannya sebagai tukang kayu. Setiap hari ia harus mengeluarkan dua dirham dari penghasilannya untuk diserahkan kepada majikannya, Mughirah, sebagai kompensasi kebebasan terbatas yang diberikan 
padanya. Dua sahabat yang dikutip Ibn Sa'ad memberikan dua jumlah yang berbeda. Ibn Shihab menyebut angka 100 dirham per bulan, sedang Abu Huwairith menyebut Abu Lu'lu'ah membayar 120 dirham per bulan. Dalam hal ini terdapat tiga nilai yang berbeda yang disebut Ibn Sa'ad.

Karena merasa jumlah yang diberikannya terlalu banyak dan memberatkan, Abu Lu'lu'ah mengadu kepada Khalifah Umar, memohonkan keringanan. Setelah menilai keahliannya bekerja dan jumlah yang diperolehnya dari pekerjaannya, ternyata Umar mengatakan jumlah itu masih wajar dan tidak perlu dikurangi. Jawaban Khalifah itulah yang menyulut kemarahan Abu Lu'lu'ah, dan kemudian berujung pada pembunuhan Umar saat shalat Subuh.

Mendengar ayahnya dibunuh, Ubaidullah ibn Umar membalas dendam dan membunuh siapa saja yang berhubungan dengan Abu Lu'lu'ah, termasuk istri, anak laki-laki dan anak perempuan Abu Lu'lu'ah, seorang pria Kristen bernama Jufaynah, bahkan seorang mu'allaf bernama Hurmuzan.

Kisah ini menjadi sangat menarik karena dalam berbagai literatur tentang Khalifah Umar selama ini tidak pernah diungkap sedikit pun kemungkinan adanya masalah pribadi yang menjadi penyebab pembunuhannya. Tidak pula diungkap tentang kekejian anaknya Ubaidullah dalam membalas dendam. Jika seandainya semua kisah tersebut benar, kita bisa menyimpulkan betapa beratnya tugas Rasulullah saw semasa hidupnya berhadapan dengan masyarakat yang bisanya menyelesaikan atau lebih tepat; melenyapkan masalahsambil menciptakan masalah baru-melalui penumpahan darah.

Menjelang akhir hayatnya, Rasulullah saw yang dalam keadaan sakit meminta dituliskan wasiat yang akan mencegah umat terpecah-belah. Umar ibn Khattab terang-terangan mengkritik Rasulullah dengan mengatakan, tidak perlu karena kita sudah punya al-Qur'an. Itu cukup untuk kita. Penolakannya kemudian menimbulkan gaduh di sekeliling Rasulullah yang menyebabkan Rasulullah menyuruh mereka semua, termasuk Umar, agar keluar dari rumahnya. Bagaimanapun, wasiat itu akhirnya tidak jadi dibuat.

Talha bin Ubaidullah Tamimi, menantu Khalifah Abu Bakar memiliki rumah di Kufah dan memperoleh penghasilan lebih dari 1.000 dinar per hari dari kawasan pertaniannya. Punya istana mewah di Madinah dan saat meninggal, ia mewariskan uang 2,2 milyar dirham dan 2 juta dinar "cash" ditambah 300 karung emas dan perak. Karungnya sangat besar, terbuat dari kulit unta" (Ibn Sa'ad, Jilid 3 : 158).

"Abdur Rahman ibn Auf adalah ipar Khalifah Usman ibn Affan dan orang yang paling berperan dalam memperjuangkan Usman sebagai Khalifah dalam persaingan dengan Ali ibn Abi Thalib. "Hasilnya" : Lebih seribu ekor unta, seratus ekor kuda, 30 ribu kambing dan domba bernilai 84 ribu dinar, dan empat isteri dimana satu diceraikannya menjelang kematiannya dan memperoleh "uang cerai” 83 ribu dinar (Ibn Sa'ad, Jilid 3 : 96).

Sahabat Rasulullah saw, Sa'd ibn Abi Waqqash mewariskan harta 2.050.000 dirham dan sebuah istana yang sangat mewah di Aqiq" (Ibn Sa'ad, Jilid 3 : 105).

"Rasulullah saw melarang pembunuhan di Tanah Haram (Makkah) kecuali pada hari ia memerintahkan pembunuhan enam lelaki dan empat wanita murtad, yaitu (1) Ikrimah Ibn Abi Jahl, (2) Habbar Ibn al-Aswad, (3) Abd Allah Ibn Sa 'd Ibn Abi Sarh, (4) Miqyas Ibn Sababah al-Laythi, (5) al-Huwayrith Ibn Nuqaydh, (6) Abd Abbah Ibn Hilal Ibn Khatal al-Adrami, (7) Hind Binti Utbah, (8) Sarah, budak Amr Ibn Hashim, (9) Fartana and (10) Qaribah" (Ibn Sa'ad, Jilid $3: 168)$.

Peristiwa pembunuhan Asma binti Marwan diceritakan sebagai berikut :

"Pada malam 25 Ramadlan, 19 bulan pasca-Hijrah, Umayr ibn Adi yang buta memasuki rumah Asmi binti Marwan dan membunuh istri Yazid ibn Zayd ibn Khisn al-Khatmi. 
Alasannya, Asma menulis syair yang isinya menentang Rasulullah saw dan menghasut masyarakat untuk murtad. Seusai shalat Subuh, Rasulullah bertanya kepada Umayr : "Apakah kau telah membunuh putri Marwan?" Umayr menjawab : "Ya. Apakah ada lagi yang harus kukerjakan?" "Tidak," jawab Rasulullah. Rasulullah juga menjuluki Umayr yang buta sebagai "Bashir"”" (Ibn Sa'ad, Jilid 3 : 31).

Kisah yang diungkap Ibn Sa'd di atas meragukan sebab tidak cukup alasan syari untuk membunuh Asma. Lebih dari itu, salah satu narasumber periwayatan kisah tersebut tercatat adalah Muhammad Ibn al-Hajjaj yang dituduh sebagai penyebar hadis palsu Karenanya, tabaqat ini nampaknya harus dibaca dengan sikap kritis dan tenang.

\section{Thabaqat asy-Syafi iyah}

Thabaqat asy-Syafi 'iyah karya: Ibn Qadhiy Syuhbah. Kitab ini ditulis selesai pada bulan Zu al-Qa dah tahun $841 \mathrm{H}$.

\section{Nama Penulis}

Penulis kitab ini nama lengkapnya adalah: Abu Bakar Ibn Ahmad Ibn Muhammad Ibn Umar Ibn Muhammad Ibn Abdul Wahhab Ibn Dzuaib al-Asadiy Ibn Qadhiy Syuhbah asySyafi iy (Ibn Qadhiy Syuhbah, Maktabah Syamilah al-Ishdar ats-Tsani : 221).

Kitab ini ada dimuat dalam Maktabah Syamilah al-Ishdar ats-Tsani dalam kelompok Tarajim Wa Thabaqat yang disadur dari Internet: http://www.alwarraq.com, namun penomoran halaman yang ada dalam Maktabah Syamilah tidak sesuai dengan penomoran halaman dalam kitab yang dicetak, dan penulis hanya mendapatkan buku ini dalam Maktabah Syamilah tersebut.

\section{Konteks Penulisan}

Penulisan kitab ini dalam konteks sejarah yaitu kumpulan biografi orang-orang terpilih atau ulama dalam bidang fiqh mazhab Syafi i dan pengelompokan mereka berdasarkan priode masa hidupnya. Di antara catatan biografi yang dikemukakan dalam kitab thabaqat ini adalah tahun kelahiran dan tahun wafat masing-masing (terkadang disebutkan hari, bulan dan terkadang disebutkan pula saat atau waktunya seperti subuh, zuhur atau malam dan sebagainya), nama orang tuanya, nama kakeknya, nama laqab dan kuniyabnya, kegiatan rihlah ilmiahnya, keahliannya, karya-karyanya di bidang fiqh dan dalam bidang lainnya, dan kata-kata sanjungan terhadapnya serta dikemukakan pula sebagian lembaga pendidikan yang telah mereka bangun atau meneruskan fungsi atau kedudukan orang tuanya baik sebagai guru maupun sebagai pimpinan lembaga pendidikan. 


\section{Isi Kandungan Kitab}

Kitab ini berisi 221 halaman dan mengemukakan biografi tidak kurang dari tujuh ratus tujuh puluh lima (775) orang tokoh atau orang alim di bidang fiqh mazhab Syafi i yang hidup dalam rentang waktu lebih dari enam setengah abad (yaitu dari tiga puluh tahun terakhir abad yang kedua hijriyah sampai dua puluhan kedua abad kesembilan hijriyah).

Dalam kitab ini mereka dibagi atau dikategorikan dalam dua puluh sembilan thabaqat (kelompok). Diawali dari kelompok ulama yang pernah belajar dengan atau pernah menjadi murid-murid Imam Syafi i secara langsung dan diakhiri dengan kelompok ulama Syafi iyah yang hidup pada dua puluhan tahun ke dua abad kesembilan hijriyah. Secara rinci dua puluh sembilan thabaqat (kelompok) tersebut adalah:

Thabaqat I tentang ulama atau orang-orang alim yang pernah belajar langsung dengan Imam Syafi i. Pada thabaqat ini dikemukakan sebanyak 17 nama tokoh.

Thabaqat II tentang ashhab Syafi iy yang tidak sempat ketemu dengannya. Pada thabaqat ini dikemukakan sebanyak 13 nama tokoh.

Thabaqat III tentang ulama Syafi iyah yang hidup pada dua puluhan tahun pertama abad keempat hijriyah. Pada thabaqat ini dikemukakan sebanyak 20 nama tokoh.

Thabaqat IV tentang ulama Syafi iyah yang hidup pada dua puluhan tahun kedua abad keempat hijriyah. Pada thabaqat ini dikemukakan sebanyak 20 nama tokoh.

Thabaqat $\mathrm{V}$ tentang ulama Syafi iyah yang hidup pada dua puluhan tahun ketiga abad keempat hijriyah. Pada thabaqat ini dikemukakan sebanyak 20 nama tokoh.

Thabaqat VI tentang ulama Syafi iyah yang hidup pada dua puluhan tahun ke empat abad keempat hijriyah. Pada thabaqat ini dikemukakan sebanyak 22 nama tokoh.

Thabaqat VII tentang ulama Syafi iyah yang hidup pada dua puluhan tahun terakhir abad keempat hijriyah. Pada thabaqat ini dikemukakan sebanyak 16 nama tokoh.

Thabaqat VIII tentang ulama Syafi iyah yang hidup pada dua puluhan tahun pertama abad kelima hijriyah. Pada thabaqat ini dikemukakan sebanyak 31 nama tokoh.

Thabaqat IX tentang ulama Syafi iyah yang hidup pada dua puluhan tahun kedua abad kelima hijriyah. Pada thabaqat ini dikemukakan sebanyak 19 nama tokoh.

Thabaqat X tentang ulama Syafi iyah yang hidup pada dua puluhan tahun ketiga abad kelima hijriyah. Pada thabaqat ini dikemukakan sebanyak 18 nama tokoh.

Thabaqat XI tentang ulama Syafi iyah yang hidup pada dua puluhan tahun keempat abad kelima hijriyah. Pada thabaqat ini dikemukakan sebanyak 22 nama tokoh.

Thabaqat XII tentang ulama Syafi iyah yang hidup pada dua puluhan tahun terakhir abad kelima hijriyah. Pada thabaqat ini dikemukakan sebanyak 20 nama tokoh. 
Thabaqat XIII tentang ulama Syafi iyah yang hidup pada dua puluhan tahun pertama abad keenam hijriyah. Pada thabaqat ini dikemukakan sebanyak 20 nama tokoh.

Thabaqat XIV tentang ulama Syafi iyah yang hidup pada dua puluhan tahun kedua abad keenam hijriyah. Pada thabaqat ini dikemukakan sebanyak 20 nama tokoh.

Thabaqat XV tentang ulama Syafi iyah yang hidup pada dua puluhan tahun ketiga abad keenam hijriyah. Pada thabaqat ini dikemukakan sebanyak 17 nama tokoh.

Thabaqat XVI tentang ulama Syafi iyah yang hidup pada dua puluhan tahun keempat abad keenam hijriyah. Pada thabaqat ini dikemukakan sebanyak 18 nama tokoh.

Thabaqat XVII tentang ulama Syafi iyah yang hidup pada dua puluhan tahun terakhir abad keenam hijriyah. Pada thabaqat ini dikemukakan sebanyak 29 nama tokoh.

Thabaqat XVIII tentang ulama Syafi iyah yang hidup pada dua puluhan tahun pertama abad ketujuh hijriyah. Pada thabaqat ini dikemukakan sebanyak 18 nama tokoh.

Thabaqat XIX tentang ulama Syafi iyah yang hidup pada dua puluhan tahun kedua abad ketujuh hijriyah. Pada thabaqat ini dikemukakan sebanyak 31 nama tokoh.

Thabaqat XX tentang ulama Syafi iyah yang hidup pada dua puluhan tahun ketiga abad ketujuh hijriyah. Pada thabaqat ini dikemukakan sebanyak 27 nama tokoh.

Thabaqat XXI tentang ulama Syafi iyah yang hidup pada dua puluhan tahun keempat abad ketujuh hijriyah. Pada thabaqat ini dikemukakan sebanyak 30 nama tokoh.

Thabaqat XXII tentang ulama Syafi iyah yang hidup pada dua puluhan tahun terakhir abad ketujuh hijriyah. Pada thabaqat ini dikemukakan sebanyak 41 nama tokoh.

Thabaqat XXIII tentang ulama Syafi iyah yang hidup pada dua puluhan tahun pertama abad kedelapan hijriyah. Pada thabaqat ini dikemukakan sebanyak 27 nama tokoh.

Thabaqat XXIV tentang ulama Syafi iyah yang hidup pada dua puluhan tahun ke dua abad kedelapan hijriyah. Pada thabaqat ini dikemukakan sebanyak 50 nama tokoh.

Thabaqat XXV tentang ulama Syafi iyah yang hidup pada dua puluhan tahun ke tiga abad kedelapan hijriyah. Pada thabaqat ini dikemukakan sebanyak 56 nama tokoh.

Thabaqat XXVI tentang ulama Syafi iyah yang hidup pada dua puluhan tahun ke empat abad kedelapan hijriyah. Pada thabaqat ini dikemukakan sebanyak 45 nama tokoh.

Thabaqat XXVII tentang ulama Syafi iyah yang hidup pada dua puluhan tahun terakhir abad kedelapan hijriyah. Pada thabaqat ini dikemukakan sebanyak 34 nama tokoh.

Thabaqat XXVIII tentang ulama Syafi iyah yang hidup pada dua puluhan tahun pertama abad kesembilan hijriyah. Pada thabaqat ini dikemukakan sebanyak 45 nama tokoh.

Thabaqat XXIX tentang ulama Syafi iyah yang hidup pada dua puluhan tahun ke dua abad kesembilan hijriyah. Pada thabaqat ini dikemukakan sebanyak 29 nama tokoh. 
Demikian rincian dan kerapian serta tertib runtutnya sistem pengelompokan (thabaqat) dalam kitab ini dengan memuat nama-nama ulama fiqh mazhab Syafi $i$ tersebut secara berurut menurut priode masa hidupnya, seperti terlihat di atas memulai dengan kelompok (thabaqat) pertama yaitu: kelompok ulama yang pernah belajar dengan Imam Syafi i secara langsung, kemudian ulama mazhabnya akan tetapi mereka tidak sempat ketemu dengannya, lalu ulama berikutnya yang mereka hidup di dua puluhan pertama, kedua, ketiga, keempat dan terakhir abad keempat, demikian juga pada abad kelima, keenam, ketujuh, kedelapan dan terakhir kelompok ulama mazhabnya yang hidup di dua puluhan ke dua abad kesembilan hijriyah.

\section{Beberapa Sampel Ulama Beserta Biodatanya Yang Dimuat Dalam Thabaqat}

Berikut ini penulis akan kemukakan beberapa di antara ulama Syafi iyah beserta biodatanya yang dimuat dalam thabaqat ini, antara lain:

1) Imam Ahmad Ibn Hambal. Ia dimasukkan dalam thabaqat ini pada nomor urut kedua dalam thabaqat pertama. Nama lengkap dan biodatanya yang tercantun di dalamnya antara lain sebagai berikut:

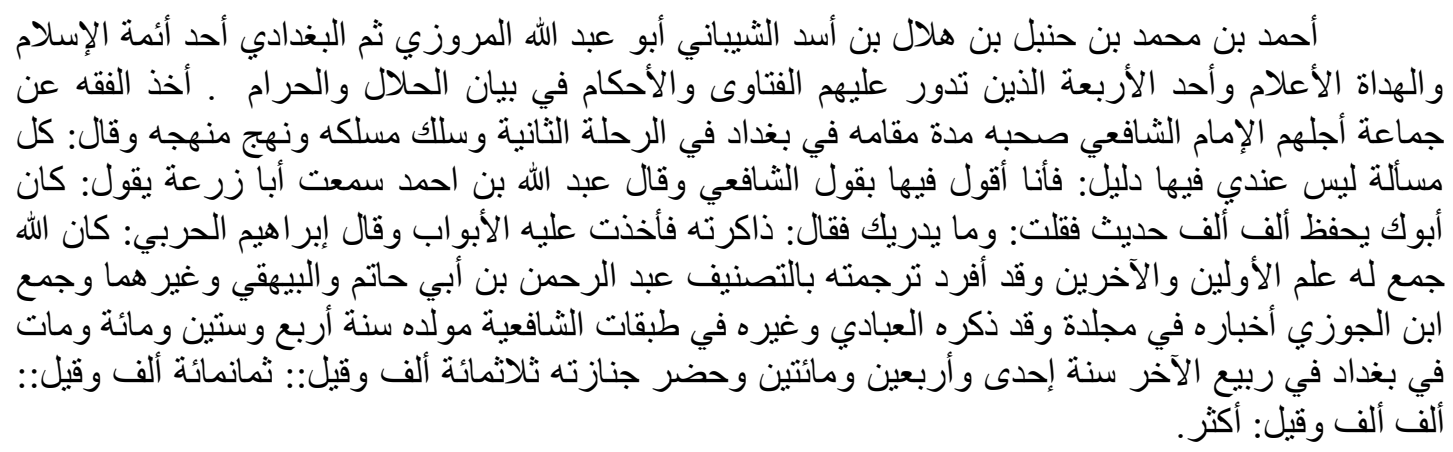

(Ibn Qadhiy Syuhbah, Maktabah Syamilah al-Ishdar ats-Tsani : 1)

Nama lengkapnya adalah: Ahmad Ibn Muhammad Ibn Hambal Ibn Hilal Ibn Asad asy-Syaibaniy Abu Abdillah al-Mawarziy al-Baghdadiy. Ia adalah salah satu pemimpin Islam dan da $i$ dunia salah satu dari empat ulama besar (ulama fiqh empat mazhab) yang di tangan mereka beredar fatwa dan berbagai hukum tentang penjelasan halal dan haram. Ia menimba ilmu bidang fiqh dari banyak ulama dan yang teristimewa Imam Syafi $i$, ia bersamanya semasa Imam Syafi $i$ menetap di Baghdad dalam pengembaraannya yang kedua. Ia menggunakan metode dan manhaj Imam Syafi i, ia pernah berkata: "Semua masalah aku tidak mempunyai dalil tentangnya: lalu aku katakan tentangnya dengan perkataan Syafi i. Abdullah Ibn Ahmad berkata: Aku telah mendengar Ayah Zar'ah berkata: Ayahmu dahulu menghapal sejuta hadis, lalu aku katakan: apa yang engkau dapatkan? Lalu ia berkata: aku selalu bermuzdakarah dengannya kemudian aku mengambil beberapa dari padanya. Berkata Ibrahim al-Harbiy: Allah telah menghimpunkan padanya ilmu orang-orang dahulu dan orang-orang kemudian dan telah dibukukan biografinya khusus oleh Adurrahman Ibn Abi al-Hatim dan Baihaqiy dan selain keduanya. Ibnu Jauziy telah mengumpulkan sejarahnya dalam satu jilid, dan al-I'badiy serta lainnya menyebutkan di thabaqah ini ia lahir pada tahun 164 dan wafat di Baghdad pada bulan Rabi ul Akhir tahun 241 dan yang menghadiri janazahnya 300.000 orang, dan ada yang mengatakan 1.000.000. orang bahkan lebih. 
2) Imam Bukhari. Ia dimasukkan dalam thabaqat ini pada nomor urut sebelas dalam thabaqat kedua. Nama lengkap dan biodatanya yang tercantum di dalamnya antara lain sebagai berikut:

$$
\begin{aligned}
& \text { محمد بن إسماعيل بن إبراهيم أبو عبد الله البخاري صاحب الصحيح. }
\end{aligned}
$$

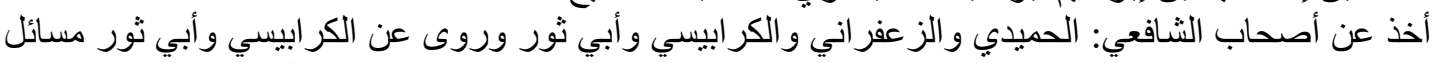

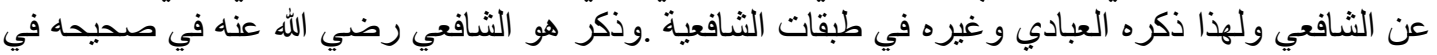

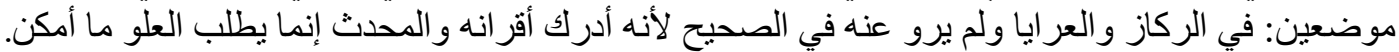

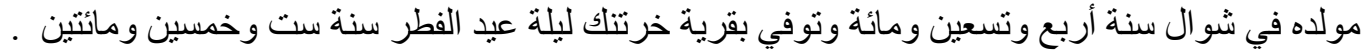

(Ibn Qadhiy Syuhbah, Maktabah Syamilah al-Ishdar ats-Tsani : 5)

Nama lengkapnya adalah Muhammad Ibn Ismail Ibn Ibrahim Abu Abdillah al-

Bukhari, pemilik kitab Shahih Bukhari. Ia menimba ilmu dari sahabat-sahabat Imam Syafi i; (dari) al-Humaidiy, az-Za faraniy, al-Karabisiy dan Abu Tsaur, dan ia menerima periwayatan (tahammul) dari al-Karabisiy dan Abu Tsaur masalah-masalah dari Syafi i, karenanya al-I’badi dan lainnya memasukkannya di dalam Thabaqat ini. Ia menyebutkan Imam Syafi i ra dalam kitab Shahihnya dua kali: dalam bab ar-Rikaz dan bab al-Araya dan tidak ia riwayatkan di dalam kitab Shahihnya karena ia menemukan sahabatsahabatnya. Ia seorang ahli Hadis dan ia hanya mencari suatu ketinggian yang dibolehkan. Ia lahir pada bulan Syawal tahun 194 dan wafat di desa Khartank pada malam Aidil Fitri tahun 256.

3. Imam Baihaqi. Ia dimasukkan dalam thabaqat ini pada nomor urut pertama dalam thabaqat kesepuluh. Nama lengkap dan biodatanya yang tercantum di dalamnya antara lain sebagai berikut:

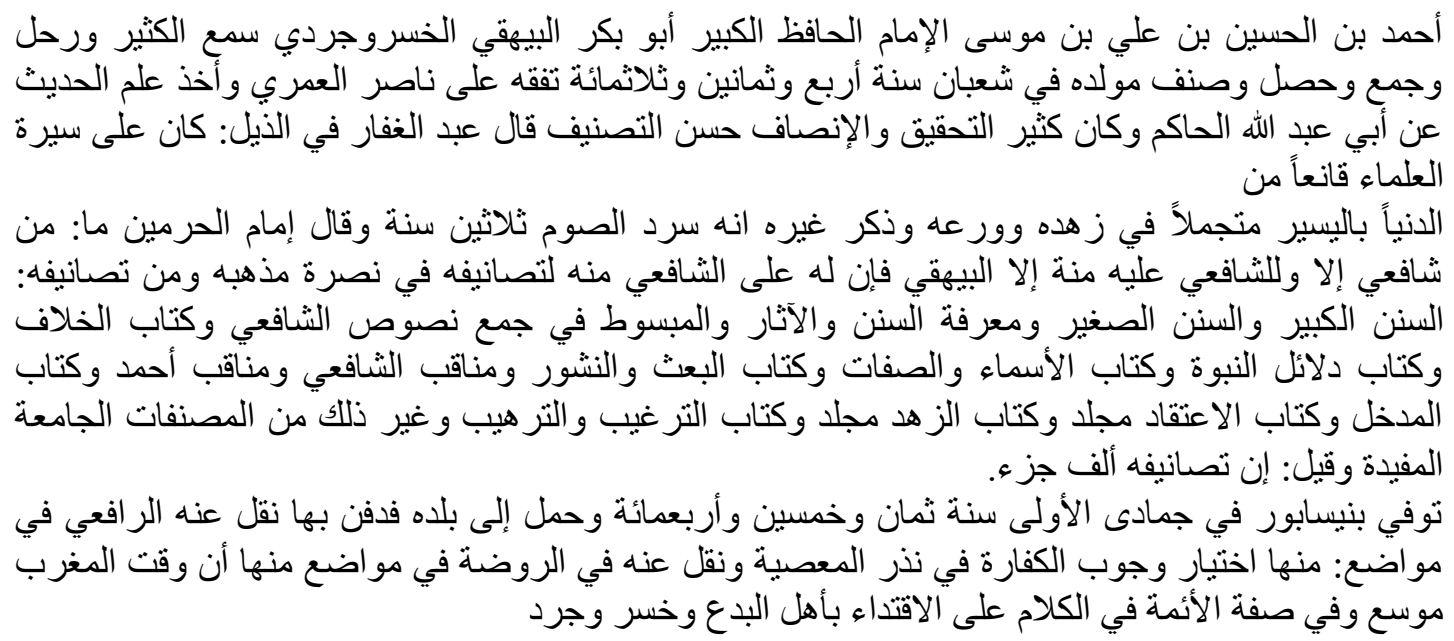

(Ibn Qadhiy Syuhbah, Maktabah Syamilah al-Ishdar ats-Tsani : 34)

Nama lengkapnya adalah Ahmad Ibn Husain Ibn Ali Ibn Musa al-Imam alHafidz besar Abu Bakar al-Baihaqiy al-Hasrujardiy. Ia banyak menerina (hadis) dengan cara sama' (seperti aku telah mendengar...), melakukan pengembaraan, menghimpun dan mendapatkan ilmu. Ia lahir pada bulan Sya 'ban tahum 384. Ia belajar Fiqh dari Nashir al-Umri dan belajar ilmu hadis dari Abu Abdillah al-Hakim. Ia banyak mentahqiq dan inshaf, bagus karangan bukunya. Abdul Ghaffar berkata tentang kerendahan hatinya: Ia menjalani hidup layaknya kehidupan ulama, qanaah, memperindah kezuhudan dan kewara annya. Orang lain menyebutkan bahwa ia berpuasa berturut-turut selama tiga puluh tahun. Imam Haramain mengemukakan: Imam Baihaqi adalah seorang Syafi iyah tulen ia menulis kitab-kitabnya untuk mendukung mazhabnya. Di antara kitab-kitab susunannya adalah: As-Sunan al-Kabir, as-Sunan ash-Shaghir, Ma rifat as-Sunan wa alAtsar, Mabsuth fi Jam`i Nushush asy-Syafi`i, Kitab al-Khilaf, Kitab Dalail an- 
Nubuwwah, Kitab Asma` wa ash-Shifat, Kitab al-Ba`tsi wa an-Nusyur, Manaqib asySyafi i, Manaqib Ahmad, Kitab al-Madkhal, Kitab al-I`tiqad, Kitab az-Zuhd, Kitab attarghib wa at-Tarhib dan lainnya, dan dikatakan orang bahwa kitab-kitab susunannya seribu juzu`.

Ia wafat di Naisabur pada bulan Jumadil awwal tahun 458 dan janazahnya dibawa ke kampung halamannya. Imam ar-Rafi ${ }^{i}$ telah menukil dari padanya dalam beberapa karyanya, di antaranya: adanya pilihan tentang wajibnya kaffarah pada nadzar maksiat. Juga dinukil dari padanya dalam kitab ar-Raudhah dalam beberapa tempat, di antaranya pendapat bahwa waktu maghrib itu panjang dan tentang sifat para pemimpin dalam pembicaraan tentang mengikut ahli bid ’ah.

4) Imam Khathib al-Baghdadi. Ia dimasukkan dalam thabaqat ini pada nomor urut kedua dalam thabaqat kesebelas. Nama lengkap dan biodatanya yang tercantum di dalamnya antara lain sebagai berikut:

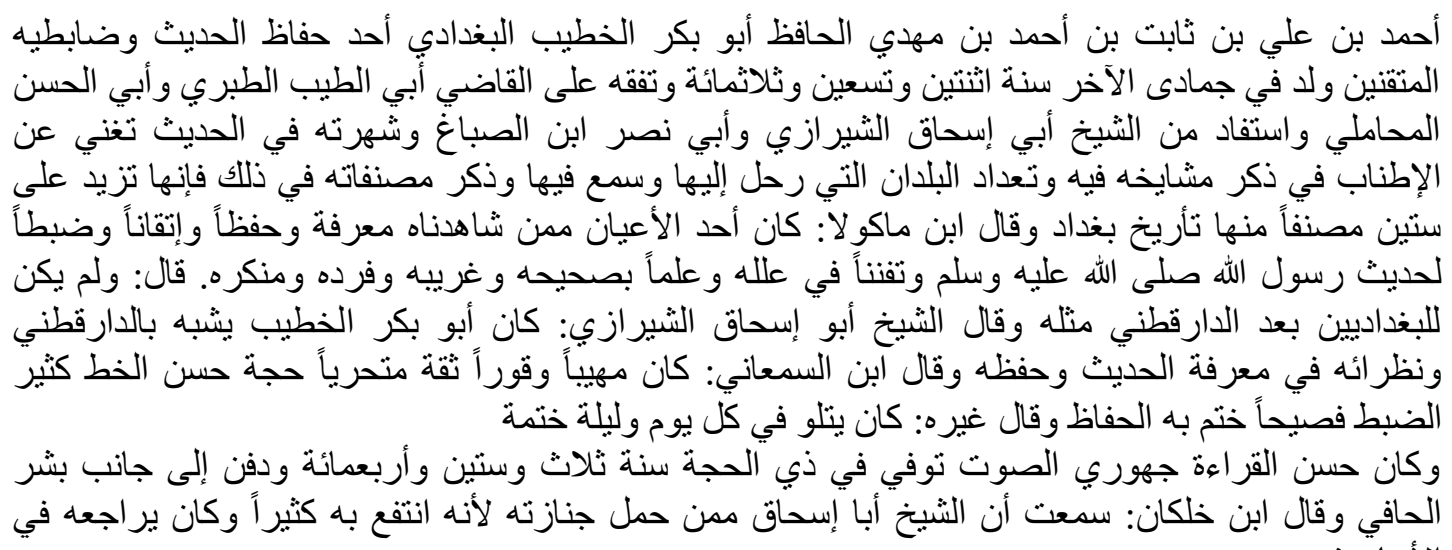

(Ibn Qadhiy Syuhbah, Maktabah Syamilah al-Ishdar ats-Tsani : 38)

Nama lengkapnya adalah Ahmad Ibn Ali Ibn Tsabit Ibn Ahmad Ibn Mahdi al-

Hafidz Abu Bakar al-Khathib al-Baghdadiy. Ia adalah salah satu buffadz hadis dan pendhobitnya yang teliti. Ia lahir pada bulan Jumadil Akhir tahun 392 dan belajar ilmu figh dari Qadhi Abu Thaib ath-Thabariy dan Abu Hasan al-Muhamiliy dan belajar tasawwuf dari asy-Syeikh Abu Ishaq asy-Syiraziy dan Abu Nashr as-Shibagh. Kemasyhuran dia di bidang Hadis kaya dengan gaya ithnabnya dalam menyebutkan gurugurunya, banyak negera yang pernah ia kunjungi dan mendengarkan pelajaran di sana, dan ia sebutkan buku-buku yang ia susun di sana jumlahnya lebih dari enam puluh karangan dan di antaranya adalah "Tarikh Baghdad" Ibnu Makula berkata: Ia adalah salah seorang person di antara orang-orang yang yang kami saksikan pengetahuannya, hafalannya, ketelitiannya, dan kedhabitannya terhadap hadis Rasulullah saw serta keahliannya di bidang illah dan pengetahuan tentang keshahihannya, kegharibannya, ketunggalannya, dan kemunkarannya. Ia berkata: Tidak ada bagi bangsa Baghdad setelah ad-Dar Quthni orang semisalnya. Syeikh Abu Ishaq asy-Syiraziy berkata: Abu bakar alKhatib ini menyerupai ad-Dar Quthni tentang kedalaman pengetahuan dan hafalannya di bidang hadis. Ibnu as-Sam `ani berkata: ia adalah seorang pemurah, sopan santun, bebas berargumentasi, indah tulisannya, banyak catatannya, dan fashih serta banyak para hafiz berhatam padanya. Sebagian orang berkata: Ia membaca al-Quran setiap harinya sekali khatam, ia bagus bacaannya dan jelas suaranya. Ia wafat pada bulan Zul Hijjah tahun 463 dan dikebumikan di samping Basyar al-Hafi, dan Ibnu Khalikan berkata: Aku telah mendengar bahwa Abu Ishaq di antara orang yang ikut membawa janazahnya karena ia telah banyak mengambil manfaat dari padanya atau dia selalu mengulang kaji hadis padanya. 
5) Imam al-Ghazali. Ia dimasukkan dalam thabaqat ini pada nomor urut keenam belas dalam thabaqat ketiga belas. Nama lengkap dan biodatanya yang tercantum di dalamnya antara lain sebagai berikut:

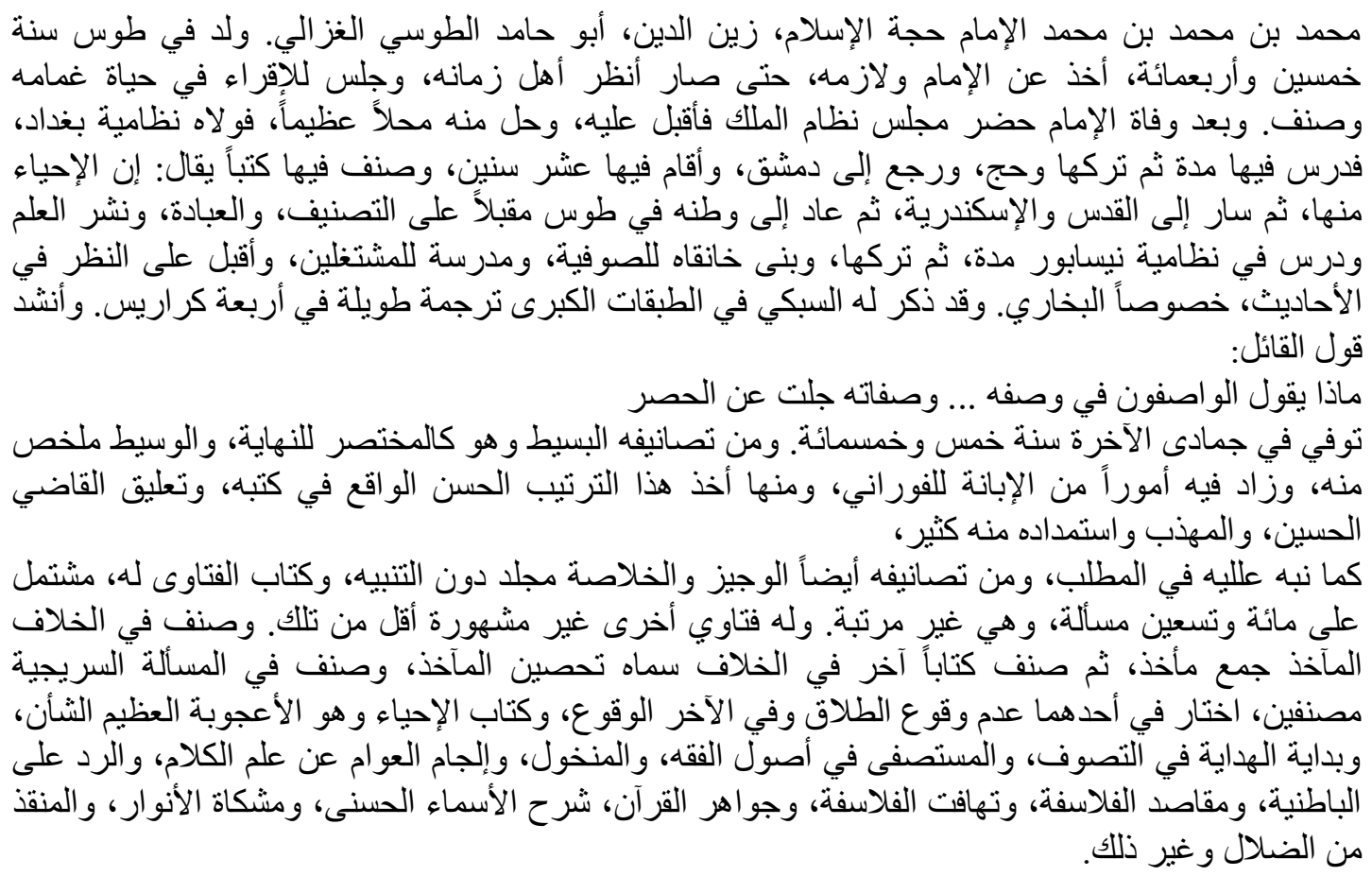

(Ibn Qadhiy Syuhbah, Maktabah Syamilah al-Ishdar ats-Tsani : 50)

Nama lengkapnya adalah: Muhammad Ibn Muhammad Ibn Muhammad alImam Hujjat al-Islam, Zainuddin Abu Hamid ath-Thusiy al-Ghazali. Ia dilahirkan di Thus tahun empat ratus lima puluh. Ia menimba ilmu dari al-Imam sehingga ia menjadi orang yang paling tajam pandangannya di kalangan ahli zamannya dan di masa suramnya ia duduk membaca dan menyusun buku. Setelah al-Imam wafat ia menghadiri Nizam alMuluk dang menghadapnya lalu ia menempati kedudukannya yang tinggi lalu ia memimpin an-Nizam di Baghdad lalu ia mengajar di sana untuk beberapa waktu, kemudian ia meninggalkannya lalu berhajji dan kembali ke Damaskus dan menetap ia di sana sepuluh tahun dan ia menyusun buku di sana yang dikatakan: sesungguhnya kitab Ibya dari kitab itu. Kemudian ia mengembara ke Bait al-Maqdis dan Iskandariah kemudian ia kembali ke kampung halamannya di Thus dan ia serius menyusun buku, ibadah, mengembangkan ilmu dan mengajar di Nizamiyah Naisabur untuk beberapa lama, kemudian meninggalkannya dan ia membangun Hanqab untuk tasawwuf dan Madrasah untuk orang-orang suluk. Selanjutnya ia mendalami bidang hadis, teristimewa hadis Bukhari. Imam Subki menyebutkannya dalam at-Thabaqat al-Kubra biografi yang panjang dalam empat kararis. Ia wafat pada bulan Jumadil Akhir tahun lima ratus lima. Di antara karya tulisnya adalah al-Basith ia adalah seperti al-Mukhtashar li an-Nihayah, dan al-Wasith keringkasan dari padanya. Dalam buku ini ia tambahkan di dalamnya beberapa permasalahan dari buku al-Ibanah karangan al-Fauriy, dan dari sini ia pakai sistematikanya yang bagus yang digunakan dalam buku ini, dan dari buku Ta'liq Abu Husain dan banyak dari buku al-Muhadzdrab dan istidadnya. 1Al-Wajir dan alKhulashabnya. Kitab al-Fatawa al-Ghazali yang berisikan seratus sembilan puluh masalah tanpa berurut. Dia juga memiliki buku Fatawa yang lain akan tetapi tidak terkenal ia lebih kecil dari buku Fatawa yang pertama. Ia juga menulis beberapa buku tentang Khilafiah salah satunya diberi nama Tahshin al-Ma kehadz dan kitab kitab al-I ya yang merupakan kitab yang sangat monumental, buku Bidayah al-Hidayah Fi at-tasamnuf, al-Musttashfa 
tentang ushul Fiqh, al-Mankhul, iljam al-awam 'an Ilm al-Kalam, Ar-Radd 'ala al-Bathiniyah, Maqshid al-Falasifah, Tahafut al-Falasifah, Jawahir al-Quran, Syarh al-Asma` al-Husna, Misykat al-Anwar, Munqidz, min adh-Dhalal dan lainnya.

\section{Relevansi karya ini dengan zamannya.}

Kitab ini ditulis pada tahun $841 \mathrm{H}$ atau sekitar tahun $1420 \mathrm{M}$ yang mana abad tersebut merupakan abad kemunduran umat Islam sekitar lebih dari satu setengah abad setelah jatuhnya Baghdad di tangan orang Mongol (Nakosteen, 1996 : 291). Menurut hemat penulis, kitab ini memperlihatkan betapa penulisnya sedemikian giatnya dalam mendata dan memuat biografi masing-masing tokoh fiqh mazhab Syafi i sampai sedemikian banyaknya. Hal ini tentu sangat bermanfaat dalam rangka menjaga dan melestarikan warisan kekayaan khazanah intelektual Muslim klasik dari sisi sejarah para tokohnya. Selain itu, hal tersebut menggambarkan masih sedemikian besarnya upaya yang dilakukan dalam mempertahankan semangat tradisi keilmuan di kalangan umat Islam di kala itu. Sekalipun mungkin tidak dalam hal mereproduksi kitab-kitab baru yang sifatnya orisinal namun paling tidak dalam upaya mempertahankan dan mencatat fakta sejarah tentang prestasi yang telah mereka capai.

\section{Potensi relevansinya saat saat ini bagi pengembangan ilmu pendidikan Islam}

Kitab ini memuat sejarah pengelompokan ulama fiqh mazhab Safi i berdasarkan pengelompokan priodesasi masa hidupnya dan sekaligus studi tokoh ulama atau biografinya. Relevansinya dengan saat ini untuk pengembangan ilmu pendidikan adalah berkenaan dengan bidang Sejarah Pendidikan Islam klasik terutama sejarah tentang tokoh atau ulama dari sisi yang sifatnya non formal dan yang unik-unik yang biasanya tidak dijumpai pada buku-buku sejarah studi tokoh pada umumnya. Genre literatur thabaqat ini dapat dipandang sebagai sumber utama (Hasan Asari, 2006 : 60-61). Selanjutnya, ulama di dunia Islam posisinya sangat penting karena mereka sebagai pewaris para nabi (Abu Isa Muhammad Ibnu Isa, 1975 M/1395 H : 48-49), tidak terkecuali pada sektor pendidikan; Mereka merupakan salah satu filar atau faktor pendidikan yang besar peran dan pengaruhnya, karena mereka sebagai tenaga pendidik dan tentunya juga sebagai tokoh yang sangat berwibawa dan sekaligus sebagai figur keteladanan dalam dunia pendidikan Islam. Mereka para alim (ulama) adalah orang-orang yang memberi pengajaran kepada para muridnya ilmu-ilmu pengetahuan yang sangat berguna, mendidik, melatih dan memberikan motivasi, baik motivasi dalam semangat menimba ilmu pengetahuan, motivasi dalam mengamalkan dan menguji coba ilmu yang telah diperoleh dan menjadi motivasi pula dalam hal membuat atau menulis buku atau karya-karya ilmiah. Selain itu ulama menjadi figur keteladanan yang dapat membangkitkan inspirasi para peserta didik untuk mengikuti jejak-jejak 
mereka dalam hal kegigihan menuntut ilmu, mengamalkan ilmunya, ketaqwaan (keteguhan iman dan amal shalih), kewara`an, sifat santun, pemurah, kasih sayang dan kesabarannya serta akblakul karimah lainnya, karena mereka adalah figur-figur idola bagi murid-muridnya.

Di sisi lain, dengan adanya thabaqat ditulis serapi dan setebal atau sebanyak itu para tokohnya, hal itu merupakan bukti tentang betapa disiplin ilmu fiqh sangat diganderungi oleh ulama pada masa lampau karena begitu besar jumlah daftar nama-nama ulama atau para tokoh fiqh mazhab Syafi i tersebut. Hal ini juga menggambarkan betapa banyak madrasah, halaqah, zawiyah dan tempat-tempat lainnya yang difungsikan sebagai lembaga pendidikan dan pengajaran pada waktu tersebut, berapa banyak pula jumlah seluruh murid di setiap lembaga tersebut, karena dari mereka yang menjadi ulama atau tokoh sedemikian banyak. Demikian juga dengan ditulisnya berbagai kitab thabaqat seperti ini memberikan gambaran kepada kita bahwa pemberian apresiasi yang besar telah diberikan kepada mereka para orang alim (ulama) dalam bidang keahliannya, dan sekaligus terhadap dunia ilmu pengetahuan. Hal ini sangat penting karena selama masyarakat atau juga pemerintah tidak mengapresiasi ilmu pengetahuan dan ahlinya dengan baik atau wajar maka perkembangan atau kemajuan ilmu pengetahuan di masyarakat atau di negeri tersebut tidak akan terjadi.

Sisi lain yang tidak kurang pentingnya, di antara mereka ada yang berhasil mendirikan lembaga pendidikan atau paling tidak menciptakan dan melestarikan halaqah keilmuan. Tradisi ini juga tentu sangat baik bila dapat dilestarikan dan dikembangkan pada era sekarang ini untuk meningkatkan semangat keilmuan dan mentradisikannya di tengah-tengah masyarakat.

Selain dari pada itu, dengan adanya kitab thabaqat seperti ini tentu dapat menimbulkan inspirasi dan motivasi untuk membukukan secara khusus atau spesifik biografi atau ensiklopedi tokoh-tokoh atau ahli-ahli pendidikan Islam baik kelas dunia atau nasional maupun tokoh atau ahli pendidikan pada umumnya.

\section{Penutup}

Dari berbagai uraian di atas dapatlah penulis kemukakan beberapa kesimpulan sebagai berikut:

1. Thabaqat adalah kumpulan biografi orang-orang terpilih dari masa lalu peradaban Islam.

2. Suatu karya di bidang ini dapat saja memilih kelompok tertentu seperti para fuqaha, para mufassir, para sasterwan, para sufi, para filosof, para ahli tata bahasa, para hakim, para rektor di satu perguruan tinggi tertentu dan seterusnya sebagai tema.

3. Pendekatan biografis membuat karya jenis ini sangat kaya dan dapat berisi apa saja. 
4. Biografi membawa satu kekuatan tersendiri karena dia merujuk langsung pada realitas kehidupan, prilaku seseorang, praktik kerjanya, metodologi yang dianutnya, dan teknik-teknik yang diterapkannya (Hasan Asari, 2008 : 53).

\section{Daftar Pustaka}

Asari, Hasan, Menguak Sejarah Mencari Ibrah, Risalah Sejarah Sosial Intelektual Muslim Klasik. Bandung: Citapustaka Media, 2006.

---------, "Pencarian Akar Keilmuan Islam, Sebuah Pemikiran Awal tentang Konseling Islam", dalam: Al-Rasyidin (Ed), Pendidikan dan Konseling Islami, Bandung:2008, Cita Pustaka Media.

Asy-Syafi i, Abu Bakar Ibn Ahmad Ibn Muhammad Ibn Umar Ibn Muhammad Ibn Abdul Wahhab Ibn Dzuaib al-Asadiy Ibn Qadhiy Syuhbah, Thabaqat asy-Syafi iyah. CD Room, Maktabah Syamilah al-Ishdar ats-Tsani.

At-Tirmizi, Abu Isa Muhammad Ibnu Isa Ibnu saurah, Sunan at-Tirmizi, Mesir: 1975 M/1395 H, Syirkah wa Maktabah wa mathba`ah Musthafa al-Babiy al-Halabiy wa Awladuh, cet. II, Juzu` V.

Nakosteen, Mehdi, Kontribusi Islam Atas Dunia Intelektual Barat, Deskripsi Analisis Abad Keemasan Islam, Surabaya: 1996, Risalah Gusti.

Lihat : http://www.sunnah.org/history/Scholars/mashaykh_azhar.htm, ia disebut sebagai syekh al-Azhar ke-39.

Lihat : http://ismaili.net/mirrors/242_azhar/azhar.htm.

http://ibnalhyderabadee.blogspot.com/2006/04/muhammad-ibn-saad.html.

http:/ / www.muftisays.com/qa.php?viewpage=viewQA\&question=2144dan

http://cwis.usc.edu/dept/MSA/fundamentals/hadithsunnah/bukhari/059.sbt.html 